
terms of the Creative Commons Attribution licence (http://creativecommons.org/licenses/by/4.0/), which permits unrestricted re-use, distribution, and reproduction in any medium, provided the original work is properly cited.

\title{
Worthless Witnesses? Marginal Voices and Women's Legal Agency in Early Modern England
}

\section{Alexandra Shepard}

\begin{abstract}
This article explores the distribution of women witnesses in a selection of English church courts between the mid-sixteenth and early eighteenth centuries, in order to assess the extent to which women's participation as witnesses in these jurisdictions might be characterized as a form of legal agency. It shows that women's participation was highly contingent on their marital status and between places and over time and was shaped by the matters in dispute as well as the gender of the litigants for whom they testified. Although poverty did not exclude women witnesses (higher proportions of female witnesses than male claimed to be poor or of limited means), women were more vulnerable than were men to discrediting strategies that cast doubt on their authority in court. Such findings show that the incorporative dimensions of state formation did not deliver new forms of agency to women but depended heavily upon patriarchal norms and constraints.
\end{abstract}

$\mathrm{n}$ recent decades, historians of early modern England have constructed a relatively optimistic account of popular legal agency, emphasizing easy access to civil litigation and broad-based participation in the implementation of the criminal law. This perspective marks a major historiographical departure from representations of the law as an oppressive instrument of social control and elite cultural hegemony. ${ }^{1}$ Rather than an index of acute antagonism, the unparalleled litigiousness that was a feature of the early modern period has been recast as a constructive and consensual means to maintain community harmony, as well as an "incorporative force" fostering state formation from the bottom up. ${ }^{2}$ Craig Muldrew has shown

\footnotetext{
Alexandra Shepard is professor of gender history at the University of Glasgow. This essay was drafted as part of the Arts and Humanities Research Council funded project Women Negotiating the Boundaries of Justice: Britain and Ireland c. 1100-c. 1750 (AH/L013568/1). She is grateful to Garthine Walker and other members of the project team, and participants at the Berkshire Conference for Women Historians, for their comments on earlier drafts. She is also very grateful for the generosity of Tim Stretton, who prepared the essay for publication while its author faced overwhelming personal circumstances.

${ }^{1}$ For classic examples, see Keith Thomas, Religion and the Decline of Magic: Studies in Popular Beliefs in Sixteenth and Seventeenth Century England (London, 1971); Douglas Hay, "Property, Authority and the Criminal Law," in Albion's Fatal Tree: Crime and Society in Eighteenth-Century England, ed. Douglas Hay, Peter Linebaugh, and E. P. Thompson (London, 1975), 17-63; Lawrence Stone, "Interpersonal Violence in English Society, 1300-1980," Past and Present, no. 101 (November 1983): 22-33.

${ }^{2}$ Steve Hindle, The State and Social Change in Early Modern England (Basingstoke, 2009), 89. See also J. A. Sharpe, "Such Disagreement betwyx Neighbours': Litigation and Human Relations in Early Modern England," in Disputes and Settlements: Law and Human Relations in the West, ed. John Bossy (Cambridge, 1983), 167-87; C. W. Brooks, Pettyfoggers and Vipers of the Commonwealth: The "Lower Branch" of the Legal Profession in Early Modern England (Cambridge, 1986); Cynthia Herrup, The Common Peace: Participation in the Criminal Law in Seventeenth-Century England (Cambridge, 1987); Craig Muldrew, The Economy of
} 
that England's local borough courts in the later sixteenth and the seventeenth century processed on average as many as one suit per household each year in peak decades, serving a "culture of reconciliation" that enabled the credit economy to function and providing a forceful equitable contrast to "prevailing notions of paternalism, deference and patriarchy." 3 Steve Hindle has argued that the law was widely used instrumentally to serve private interests in ways that expanded and shaped the local reach of the state. ${ }^{4}$ And while Michael Braddick has cautioned that the "activities of this state favoured the interests of those with significant property and of males," he has also suggested that the expanding state depended on "the participation of those who were formally subordinate" and, in particular, "the middling sort, and those among women and the poor anxious to lay claim to respectability." 5

However much the early modern English courts served as an "incorporative force" or as a socially inclusive arena, they were not without boundaries to participation or conditions attached to inclusion in litigation, not least on the basis of gender, social status, age, and marital status. The appropriation of public authority detected by Hindle largely involved middle-ranking men, and the associated state formation reinforced a growing gap between the middling sort and their poorer counterparts and rested on a largely male-specific notion of householder authority. ${ }^{6}$ Apart from the "juries of matrons" appointed to search female convicts suspected of being pregnant and to examine victims of sexual crimes, there were no official roles for women in the formal administration of the law. ${ }^{7}$ Muldrew has shown that the local borough courts (which handled relatively small claims) were not off limits to litigants in the lowest wealth bands, with the poorest entering suits against their social betters as well as against their equals, but he concedes not only that the poorer litigants were far less likely than the middle ranking to proceed to a judgment but also that women were severely underrepresented, forming less than 10 percent of his sample. ${ }^{8}$ Female litigants were not quite as marginal in other legal arenas, including most of the central courts, but although their relative presence grew with the expansion of litigation between 1580 and 1640, they remained in a minority, with the exception of

Obligation: The Culture of Credit and Social Relations in Early Modern England (Basingstoke, 1998). See also Tim Stretton, "Written Obligations, Litigation and Neighbourliness, 1580-1680," in Remaking English Society: Social Relations and Social Change in Early Modern England, ed. Steve Hindle, Alexandra Shepard, and John Walter (Woodbridge, 2013), 189-209. For an overview of developments in historians' approaches to litigiousness in early modern Europe, see Michael P. Breen, "Law, Society, and the State in Early Modern France," Journal of Modern History 83, no. 2 (June 2011): 346-86.

${ }^{3}$ Muldrew, Economy of Obligation, 271. See also Craig Muldrew, "The Culture of Reconciliation: Community and the Settlement of Economic Disputes in Early Modern England," Historical Journal 39, no. 4 (December 1996): 915-42.

${ }^{4}$ Steve Hindle, "The Keeping of the Public Peace," in The Experience of Authority in Early Modern England, ed. Paul Griffiths, Adam Fox, and Steve Hindle (Basingstoke, 1996), 213-48.

${ }_{5}$ Michael J. Braddick, State Formation in Early Modern England, c.1550-1700 (Cambridge, 2000), 174.

${ }^{6}$ For observations about the limited access of women to the politics of the parish, see Naomi Tadmor, "Where Was Mrs Turner? Governance and Gender in an Eighteenth-Century Village," in Hindle, Shepard, and Walter, Remaking English Society, 89-111.

${ }^{7}$ J. C. Oldham, "On Pleading the Belly: A History of the Jury of Matrons," Criminal Justice History, no. 6 (1985): 1-64.

${ }^{8}$ Muldrew, Economy of Obligation, 246. See also Craig Muldrew, "A Mutual Assent of Her Mind?" Women, Debt Litigation and Contract in Early Modern England," History Workshop Journal 55, no. 1 (Spring 2003): 47-71. 
defamation litigation in some branches of the church courts. ${ }^{9}$ Even where women's claims were relatively favorably received, such as in the central Court of Requests (which was another forum in which social inferiors often sued their superiors), female plaintiffs' frequent tactical deployment of the language of poverty, weakness, and subordination in pleadings often gave a double edge to the legal agency they managed to exercise. ${ }^{10}$ Perhaps as a result, historians of women have devoted as much attention to recovering the informal, sometimes quasi-legal authority of women as to establishing the character of women's representation in court. ${ }^{11}$

There remains considerable scope to clarify the boundaries surrounding women's legal participation on the basis of age and social status as well as marital status in order to refine our assessment of access to the law. While on the one hand historians' accounts of popular legal agency have routinely been gender blind, on the other hand analysis of female participation in the early modern courts has often overlooked questions of social diversity. The intersection of multiple hierarchies in early modern England compounded the marginalization of some women while creating opportunities for others, diminishing the value of generalized conclusions about female legal agency. ${ }^{12}$ Women's purchase on legal authority was both endorsed and circumscribed by the "patriarchal state," whose "incorporative force" built on gender discrimination while simultaneously empowering certain women. ${ }^{13}$

One of the obstacles to delineating the opportunities as well as the constraints that shaped women's activities in early modern courts is the difficulty of establishing biographical profiles of litigants, except in the most detailed and lengthy cases-and even here the smoke and mirrors that lawyers and litigants deployed in pleading strategies undermine the reliability of this evidence. The social composition of a wide cohort of litigants can only be recovered through painstaking record linkage

\footnotetext{
${ }^{9}$ For a summary of the proportions of female litigants in the central courts, see Tim Stretton, Women Waging Law in Elizabethan England (Cambridge, 1998), 38-42. On defamation litigation, see C. A. Haigh, "Slander and the Church Courts in the Sixteenth Century," Transactions of the Lancashire and Cheshire Antiquarian Society, no. 78 (1975): 1-13; J. A. Sharpe, Defamation and Sexual Slander in Early Modern England: The Church Courts at York (York, 1980); Martin Ingram, Church Courts, Sex and Marriage in England, 1570-1640 (Cambridge, 1987), chap. 10; Laura Gowing, Domestic Dangers: Women, Words and Sex in Early Modern London (Oxford, 1996), chap. 2. On married women's representation among litigants in various jurisdictions, see Cordelia Beattie and Matthew Frank Stevens, eds., Married Women and the Law in Premodern Northwest Europe (Woodbridge, 2013); Tim Stretton and Krista J. Kesselring, eds., Married Women and the Law: Coverture in England and the Common Law World (Montreal, 2013). See also Lloyd Bonfield, "Finding Women in Early Modern English Courts: Evidence from Peter King's Manuscript Reports," Chicago-Kent Law Review 87, no. 2 (2012): 371-92.

${ }^{10}$ Stretton, Women Waging Law; Liam J. Meyer, "Humblewise': Deference and Complaint in the Court of Requests," Journal of Early Modern Studies, no. 4 (2015): 261-85.

${ }^{11}$ For example, see Garthine Walker, "Expanding the Boundaries of Female Honour in Early Modern England," Transactions of the Royal Historical Society, no. 6 (1996): 235-45; Julie Hardwick, "Women 'Working' the Law: Gender, Authority, and Legal Process in Early Modern France," Journal of Women's History 9, no. 3 (Autumn 1997): 28-49; Laura Gowing, "Ordering the Body: Illegitimacy and Female Authority in Seventeenth-Century England," in Negotiating Power in Early Modern Society: Order, Hierarchy and Subordination in Britain and Ireland, ed. Michael J. Braddick and John Walter (Cambridge, 2001), 43-62; Laura Gowing, Common Bodies: Women, Touch and Power in Early Modern England (New Haven, 2003).

${ }^{12}$ Michael J. Braddick and John Walter, "Grids of Power: Order, Hierarchy and Subordination in Early Modern Society," in Braddick and Walter, Negotiating Power in Early Modern Society, 1-42.

${ }^{13}$ Braddick, State Formation, 172-74.
} 
undertaken in the context of a local study. ${ }^{14}$ However, dispute resolution often involved many more parties than the litigants themselves and the various court officials who oversaw and shaped proceedings. Witnesses played an instrumental role in many legal contexts, and, in the case of courts that generated depositions as part of their formal proceedings, a wealth of information has been preserved about the people summoned to testify in court. In fact, we know a good deal more about the social composition of witnesses than of litigants in such courts.

Between the mid-sixteenth and late seventeenth centuries, it was routine in English courts deploying civil law procedure to require witnesses to provide an assessment of their "worth" and to answer questions about how they made a living as part of enquiries about witness credibility. Witnesses' worth was judged with reference to the net value of their movable property, once debts owing and debts owed had been taken into account. Worth defined in such terms (often expressed as a monetary sum) served as shorthand for credit both within court and as part of a wider culture of appraisal. ${ }^{15}$ Witnesses' answers to the question of their worth provide an indication of their relative wealth and of the qualitative characteristics associated with "substance," authority and trustworthiness. Combined with the brief biographical details supplied by deponents, these estimates of worth allow some reconstruction of the social profile of the many witnesses deposing on behalf of litigants disputing a wide range of causes. In the church courts, these disputes related to defamation, will making and probate administration, the collection of tithes and church dues, the making and breaking of marriages, and a variety of offences upsetting the spiritual harmony of a parish (such as pew disputes or brawling in the churchyard). ${ }^{16}$

It has been estimated that during the early modern period as many as one in every seven adults testified on oath before the church courts at least once in their lifetime, and this was only one of the many jurisdictions in England where witnesses could appear. ${ }^{17}$ Given the numbers of deponents involved, one of the ways in which popular legalism was arguably fostered was through the commonplace experience of giving evidence in court that extended to people who were otherwise marginalized socially or politically on account of their gender, age, or relative poverty. Questions remain, of course, about the extent to which acting as a witness merely involved serving as a mouthpiece for others' interests, ventriloquizing scripts dictated by legal officials and/or social superiors. ${ }^{18}$ However, at the very least, appearing in

${ }^{14}$ See, for example, Muldrew, Economy of Obligation, chap. 8; Griet Vermeesch, "The Social Composition of Plaintiffs and Defendants in the Peacemaker Court, Leiden, 1750-54," Social History 40, no. 2 (April 2015): 208-29.

${ }_{15}$ Alexandra Shepard, Accounting for Oneself: Worth, Status and the Social Order in Early Modern England (Oxford, 2015).

${ }^{16}$ On the jurisdiction, process, and business of the church courts, see R. H. Helmholz, The Oxford History of the Laws of England, vol. 1: The Canon Law and Ecclesiastical Jurisdiction from 597 to the 1640s (Oxford, 2004).

${ }^{17}$ Colin R. Chapman, Ecclesiastical Courts, Their Officials and Their Records (Dursley, 1992).

${ }^{18}$ Christine Churches, “The Most Unconvincing Testimony': The Genesis and Historical Usefulness of the County Depositions in Chancery," Seventeenth Century 11, no. 2 (September 1996): 209-27; Bronach Kane and Fiona Williamson, eds., Women, Agency and the Law, 1300-1700 (London, 2013). See also Frances E. Dolan, True Relations: Reading, Literature, and Evidence in Seventeenth-Century England (Philadelphia, 2013); Tim Stretton, "Women, Legal Records and the Problem of the Lawyer's Hand," Journal of British Studies 58, no. 4 (October 2019), 684-700. On subornation, see Steve Hindle, "Bleeding Afreshe?": The Affray and Murder at Nantwich, 19 December 1572," in The Extraordinary and the 
court exposed witnesses to legal culture and bound them into the formal processes of dispute resolution, cementing their inclusion within what Julie Hardwick has termed "litigation communities."19

The selection of witnesses could be a fraught process, invoking or testing individuals' personal and economic obligations to neighbors, kin, or employers and regularly giving rise to accusations of bias and perjury. ${ }^{20}$ The influential jurist Sir Edward Coke was scathing about what he perceived to be a growing willingness to lie under oath for direct gain or for self-preservation, and many critics singled out church court deponents as being particularly suspect. ${ }^{21}$ Under medieval law, perjury was largely an ecclesiastical offence, as it concerned lying under oath. The Elizabethan Statute of Perjury sought to extend the secular reach of this "crime" to witnesses in all common law and prerogative or equity courts but did not include church courts, with the result that "for perjury concerning any temporall act, the ecclesiastical court hath no jurisdiction."22 In theory, false testimony in church courts remained a matter for those courts alone, but the main penalty that they offered-excommunication-was beginning to lose its purchase in Elizabethan England, and grieved parties increasingly turned to Star Chamber for relief, drawn by its more immediate penalties, which included fines and whipping. ${ }^{23}$ Many common lawyers viewed ecclesiastical procedure with suspicion, objecting to the taking of depositions in private without the possibility of direct cross-examination and the requirement of a minimum of only two deponents. As Sir John Fortescue reflected, "He who cannot find, out of all the men he knows, two who are so lacking in conscience and truth, that for fear, love, or advantage, they will contradict every truth, is deemed feeble and of little diligence." He went on to conclude, "O! what horrible and detestable diversity often ensues from the method of proceeding by the deposition of witnesses!'24 Yet despite the circulation of these negative attitudes in some quarters, serving as a witness could offer deponents the chance to voice their own judgments about the principles of social and moral order and to claim a position of authority or at least confirm their respectability in articulating community norms.

Everyday in Early Modern England: Essays in Celebration of the Work of Bernard Capp, ed. Angela McShane and Garthine Walker (Basingstoke, 2010), 224-45; Barbara Shapiro, "Oaths, Credibility and the Legal Process in Early Modern England: Part 1," Law and Humanities 6, no. 2 (December 2012): 145-78; Barbara Shapiro, "Oaths, Credibility and the Legal Process in Early Modern England: Part 2," Law and Humanities 7, no. 1 (June 2013): 19-54.

${ }^{19}$ Julie Hardwick, Family Business: Litigation and the Political Economics of Daily Life in Early Modern France (Oxford, 2009), 90-92.

${ }^{20}$ Hillary Taylor, "The Price of the Poor's Words: Social Relations and the Economics of Deposing for One's 'Betters' in Early Modern England," Economic History Review 73, no. 3 (August 2019): 828-47.

${ }^{21}$ Sir Edward Coke in Slade's case, 4 Co. Rep. 9la at 95a; J. H. Baker and S. F. C. Milsom, Sources of English Legal History: Private Law to 1750 (London, 1986), 441.

${ }_{22}$ Statute of Perjury, 1563, 5 Eliz. c. 9; Edward Coke, The Third Part of the Institutes of the Laws of England, 6th ed. (1680), 164.

${ }^{23}$ In 1590, judges in King's Bench had to decide if the court could hear a defamation suit over the words "Pierce hath taken a false oath in the Consistory Court at Exeter." After much deliberation, the judges heard the case and found for Pierce; Pierce v. Howe 1 Leon. 131. See Michael D. Gordon, "The Invention of a Common Law Crime: Perjury and the Elizabethan Courts," American Journal of Legal History 24, no. 2 (April 1980): 145-70, at 155.

${ }_{24}$ Sir John Fortescue, On the Laws and Governance of England, ed. Shelley Lockwood (Cambridge, 1997), 30, 47. 
This essay draws on a dataset of over 13,500 witnesses' responses to the question of their worth, compiled as part of a larger project, in order to quantify numbers of female deponents geographically and across time, establish their social backgrounds, and explore the terms on which they participated in court. ${ }^{25}$ Deposition evidence is not always reliable, but reasons exist to assume that witnesses were far less likely to lie about their own worth than about the matters in dispute, given the openness of declarations of worth to public scrutiny, discussion, and corroboration. ${ }^{26}$ The chosen samples reveal how witness populations included proportions of women comparable to those represented among litigants, and that witnesses of little worth appeared alongside their more substantial counterparts. The centrality of female witnesses as well as litigants in the large volume of business devoted to defamation suits is well known to historians, and women were also relatively well represented among witnesses in matrimonial and testamentary causes. Clearly, not all women witnesses were deemed "worthless," despite their propensity to describe themselves as being of little or no worth. However, it is apparent that the words of women (particularly those of limited means) were not always taken as seriously as those of men, with accusations of poverty and untrustworthiness featuring in discrediting strategies that disproportionately questioned the authority of women and those of little worth. Poorer women were therefore doubly disadvantaged, suggesting that the process of assembling witnesses served to reinforce rather than cut across social boundaries and the gender divide, however much it served to include women in the "mundanity" of early modern litigation and legal culture. ${ }^{27}$

Women's participation as witnesses in court, while extensive, was nonetheless limited compared to men's. Table 1 represents the incidence of female witnesses and its variation between places (corresponding to jurisdictional boundaries) and over time. ${ }^{28}$ Overall, female witnesses comprise a quarter of the dataset, although there were substantial differences between jurisdictions. Women were well represented in London and the South East, whereas they made up only one in ten of the witnesses called to testify in the Diocese of York. Women's presence among witnesses also increased over time (at least in London and the South East), although, with the exception of London, the numbers involved were relatively small, owing to the reduced and contracting volume of litigation following the resumption of church court business after 1660 .

Married women were more likely to appear as witnesses than were their single or widowed counterparts. Table 2 represents the incidence of women witnesses according to their marital status, and shows the overrepresentation of wives that is

\footnotetext{
${ }^{25}$ Shepard, Accounting for Oneself. The compilation of this dataset, a version of which is available from the UK Data Archive, was funded by a grant from the Economic and Social Research Council (RES-00023-1111) and completed with the research assistance of Dr. Judith Spicksley. The data was drawn from depositions generated by the dioceses of Canterbury, Chester, Chichester, Ely, London, Salisbury, and York (including the archdeaconry records of Lewes and Richmond), and from the Cambridge University Courts (which also deployed civil law procedure).

${ }^{26}$ The accuracy of witnesses' statements of worth is discussed at length in Alexandra Shepard and Judith Spicksley, "Worth, Age and Social Status in Early Modern England," Economic History Review 64, no. 2 (May 2011): 493-530.

${ }^{27}$ Hardwick, Family Business, 60.

${ }^{28}$ Shepard, Accounting for Oneself, 19.
} 
Table 1-Proportions of Female Witnesses, by Jurisdiction and over Time (\%). Source: Depositions generated by the dioceses of Canterbury, Chester, Chichester, Ely, London, Salisbury, and York, and the Cambridge University courts.

\begin{tabular}{|c|c|c|c|c|c|c|c|c|}
\hline & $1550-1574$ & $1575-1599$ & $1600-1624$ & $1625-1649$ & $1657-1681$ & $1682-1706$ & $1707-1728$ & $1550-1728$ \\
\hline Cambridge \& Ely & - & 21 & 23 & 19 & 28 & - & - & 22 \\
\hline Canterbury & 22 & 24 & 24 & 32 & 55 & 35 & - & 27 \\
\hline Chester \& Richmond & - & 16 & 23 & 26 & 28 & - & - & 25 \\
\hline Chichester \& Lewes & - & 12 & 23 & 26 & 67 & 6 & - & 21 \\
\hline London & 30 & 28 & 37 & 42 & 47 & 54 & 44 & 42 \\
\hline Salisbury & 20 & 20 & 19 & 18 & 21 & 30 & 16 & 19 \\
\hline York & 6 & 9 & 11 & 10 & 16 & 8 & - & 10 \\
\hline ALL & 13 & 21 & 22 & 26 & 29 & 47 & 39 & 24 \\
\hline
\end{tabular}


Table 2-Marital Status of Female Witnesses, by Jurisdiction (\%). Source: Depositions generated by the dioceses of Canterbury, Chester, Chichester, Ely, London, Salisbury, and York, and the Cambridge University courts.

\begin{tabular}{lccc}
\hline & Single & Married & Widowed \\
\hline Cambridge \& Ely & 15 & 74 & 12 \\
Canterbury & 16 & 66 & 19 \\
Chester \& Richmond & 16 & 59 & 25 \\
Chichester \& Lewes & 30 & 50 & 20 \\
London & 20 & 58 & 21 \\
Salisbury & 23 & 60 & 16 \\
York & 26 & 53 & 21 \\
ALL & 20 & 61 & 19 \\
\hline
\end{tabular}

indicative of their comparative authority and sometimes their centrality to matters in dispute. However, at least 447 (24 percent) of the wives called as witnesses were cited alongside their spouses, suggesting that the women's authority was either shared with or conferred by their husbands. Of the singlewomen in the sample, 70 percent identified themselves as servants, which raises the question of whether singlewomen's presence amongst witnesses was more heavily dependent than men's on their household connections. Because male witnesses provided almost no information about their marital status, it is impossible to make a direct comparison. ${ }^{29}$ However, a much lower proportion of all male witnesses ( 5 percent) identified themselves as servants than did the overall proportion of female witnesses who declared they were in service (12 percent).

Because of women's routine categorization by marital status, the social composition of women called as witnesses is difficult to reconstruct. ${ }^{30}$ Nonetheless, there are several indicators of social status that can be explored to tease out more information than is available about female litigants in these same courts. The statements of worth that witnesses provided can function as a gauge of relative wealth, although less reliably so for women. The majority of witnesses responded to the question of what they were worth with an estimate of the net value of their movable property, expressed as a cash sum. This mode of assessment was not a quirk of court procedure but a common part of a deeply embedded culture of appraisal in which the quantification of goods served as a key determinant of credit and demarcated a wide range of social benchmarks and political thresholds. ${ }^{31}$ Men deployed this mode of self-description in response to the question of their worth much more frequently than did women, and they also claimed possession of property of far greater value.

\footnotetext{
${ }^{29}$ Almost all (93 percent) of the observations of men's marital status occurred when identified with their wives on their being called together as witnesses.

${ }^{30}$ For the pitfalls of interpreting labels that apparently signal marital status, see Amy L. Erickson, "Mistresses and Marriage: or, a Short History of the Mrs," History Workshop Journal 78, no. 1 (Spring 2014): 39-57; J. H. Baker, "Male and Married Spinsters," American Journal of Legal History 21, no. 3 (July 1977): 255-59.

${ }^{31}$ Shepard, Accounting for Oneself, chap. 3.
} 
Table 3-Categories of Response to the Question of Worth by Gender and Marital Status (\%). Source: Depositions generated by the dioceses of Canterbury, Chester, Chichester, Ely, London, Salisbury, and York, and the Cambridge University courts.

\begin{tabular}{lcccrc}
\hline Category of Response & All Men & All Women & Singlewomen & Wives & Widows \\
\hline Cash estimate of worth in goods & 74 & 16 & 26 & 1 & 46 \\
Little/nothing/poor & 10 & 43 & 51 & 44 & 32 \\
Other & 16 & 41 & 33 & 55 & 22 \\
\hline
\end{tabular}

Men's greater reliance on claims to "worth" couched in financial terms is demonstrated in table 3 . Nearly three-quarters ( 74 percent) of all male witnesses responded to the question of their worth with a positive cash estimate of the value of their goods, whereas only 16 percent of female witnesses responded in such terms. This disparity is partly attributable to the propensity of wives to pay lip service to marital property law (which denied them ownership of movable property) by declaring themselves worth little or nothing, often explicitly on account of being married, or to evade the question altogether by responding that it did not concern them-even though many wives nonetheless also articulated indirect claims to marital property if not direct ownership of it. ${ }^{32}$ However, the proportions of both singlewomen (26 percent) and widows (46 percent) providing a positive monetary assessment of their net movable wealth were also considerably lower than the proportion of all male witnesses, notwithstanding women's theoretical enjoyment of comparable property rights with men.

Because information about male witnesses' marital status is relatively limited, and because wealth differentials depended on many other variables in addition to gender and marital status, it is difficult to establish informative comparisons between the men and women in the dataset. Nevertheless, the juxtaposition of the cash sums cited by a few groups, as detailed in Table 4 , remains instructive. Table 4 shows the range of monetary estimates provided by different groups, according to gender, marital status, and social status, and their mean and median worth, expressed (for ease of comparison) in pounds sterling represented in decimal terms. When the monetary estimates of worth provided by female and male servants are compared, with the exception of the first quarter (1550-1574), the women were worse off than the men according to every measure, with a narrower range of sums cited and lower mean and median worth. The divergence between the levels of worth claimed by male and female servants also grew over time. When widows' worth is compared to that of laborers, husbandmen, and yeomen, widows too appear to have been disadvantaged at least in part by their gender. ${ }^{33}$ Widows' median worth resembled, or dipped below, that of laborers. Even though widows cited a wider range of wealth and higher mean worth than did laboring men, the resources to

\footnotetext{
${ }^{32}$ Alexandra Shepard, "The Worth of Married Women in the English Church Courts, c.1550-1730," in Beattie and Stevens, Married Women and the Law in Premodern Northwest Europe, 191-211; Amy Louise Erickson, "Possession - and the Other One-Tenth of the Law: Assessing Women's Ownership and Economic Roles in Early Modern England,” Women's History Review 16, no. 3 (July 2007): 369-85.

${ }^{33}$ Amy Louise Erickson, "Coverture and Capitalism," History Workshop Journal 59, no. 1 (Spring 2005), $1-16$, at 3-4.
} 
Table 4-Monetary Evaluations of Worth (in $£$ ), by Gender, Social Status, and Marital Status. Source: Depositions generated by the dioceses of Canterbury, Chester, Chichester, Ely, London, Salisbury, and York, and the Cambridge University courts.

\begin{tabular}{|c|c|c|c|c|c|c|c|c|c|c|c|c|}
\hline \multirow[b]{2}{*}{ Group } & \multicolumn{3}{|c|}{$1550-1574$} & \multicolumn{3}{|c|}{$1575-1599$} & \multicolumn{3}{|c|}{$1600-1624$} & \multicolumn{3}{|c|}{$1625-1649$} \\
\hline & Range & Mean & Median & Range & Mean & Median & Range & Mean & Median & Range & Mean & Median \\
\hline Female servants & 20.00 & 2.20 & 1.00 & 6.00 & 0.83 & 0.00 & 40.00 & 1.65 & 0.00 & 100.00 & 3.45 & 0.00 \\
\hline Male servants & 20.00 & 3.20 & 1.00 & 66.67 & 3.05 & 1.00 & 100.00 & 6.76 & 1.00 & 666.67 & 15.43 & 1.25 \\
\hline Yeomen & 40.00 & 9.88 & 20.00 & 500.00 & 26.97 & 10.00 & $1,000.00$ & 85.39 & 40.00 & $1,500.00$ & 143.06 & 100.00 \\
\hline Husbandmen & 200.00 & 8.03 & 5.00 & 133.33 & 10.72 & 5.00 & 500.00 & 20.33 & 10.00 & 500.00 & 29.04 & 10.00 \\
\hline Labourers & 10.00 & 2.03 & 2.00 & 20.00 & 3.66 & 2.00 & 50.00 & 4.32 & 2.00 & 60.00 & 4.75 & 2.00 \\
\hline Widows & 90.00 & 9.78 & 2.00 & 100.00 & 6.34 & 1.25 & 100.00 & 8.50 & 2.00 & 300.00 & 16.71 & 2.00 \\
\hline
\end{tabular}


Table 5-Categories of Response to the Question of Worth by Gender and Age (\%). Source: Depositions generated by the dioceses of Canterbury, Chester, Chichester, Ely, London, Salisbury, and York, and the Cambridge University courts.

\begin{tabular}{|c|c|c|c|c|c|c|c|c|}
\hline \multirow[b]{3}{*}{ Category of response } & \multicolumn{8}{|c|}{ Age group } \\
\hline & \multicolumn{2}{|l|}{$<25$} & \multicolumn{2}{|c|}{$25-39$} & \multicolumn{2}{|c|}{$40-54$} & \multicolumn{2}{|l|}{$55+$} \\
\hline & Men & Women & Men & Women & Men & Women & Men & Women \\
\hline $\begin{array}{l}\text { Cash estimate of worth } \\
\text { in goods }\end{array}$ & 49 & 17 & 75 & 13 & 77 & 13 & 77 & 28 \\
\hline Little/nothing/poor & 30 & 52 & 10 & 44 & 7 & 41 & 7 & 37 \\
\hline Other & 21 & 31 & 15 & 43 & 16 & 46 & 16 & 35 \\
\hline
\end{tabular}

which widows laid claim were dwarfed by the sums cited by relatively wealthy husbandmen and increasingly wealthy yeomen by the beginning of the seventeenth century. In both comparisons, therefore, the median worth of female servants and widows was relatively low, and, although the range of wealth cited by widows was considerably wider than that of laborers (as we would expect), it did not match that of either husbandmen or yeomen in any period.

Women witnesses were also much more likely than were male witnesses to describe themselves as being worth little or nothing and to deploy the language of poverty when speaking about themselves. As shown in table 3, more than half of all singlewomen and nearly a third of widows claimed to be worth little or nothing or poor, whereas only 10 percent of male witnesses spoke in such terms about their worth. Table 5, which plots categories of response to the question of a witness's worth according to gender and age, shows that women's association with more limited means remained strong over the course of the life cycle, while men's association with limited means diminished much more markedly with age as their property interests increased. Women witnesses also used the explicit language of poverty to describe themselves with a little more facility than did men. Five percent of women witnesses described themselves or their spouse as "poor" compared to 2 percent of male witnesses. Widows referred to their poverty with the greatest frequency, with 8 percent claiming to be "poor." Besides signaling material hardship, the language of poverty also carried strong associations with dependence and could principally denote social subordination rather than indigence. In women's use of the language of poverty, however, both meanings frequently converged. ${ }^{34}$

These points illustrate the constraints on women's direct ownership of resources rather than a preference among litigants for women of lower social status-although the higher levels of poverty among women witnesses suggest that, when it came to witness selection, a woman's lack of means was perhaps less of an issue than was the case for men. As indicated above, the underlying premise of enquiries into the worth of witnesses was that the possession of wealth diminished the temptation or

\footnotetext{
${ }^{34}$ Alexandra Shepard, "Poverty, Labour, and the Language of Social Description in Early Modern England," Past and Present, no. 201 (November 2008): 51-95.
} 
possibility of bribery. ${ }^{35}$ By implication, poor witnesses were untrustworthy because they would, in contemporary parlance, "swear to anything for a pot of ale." 36 Dependent witnesses were also doubtful, on account of their ties of obligation to social superiors to whom they were beholden and by whom they might be coerced. Such concerns were articulated in strategies pursued by several litigants to discount their opponents' witnesses, and were anticipated in the responses of less well-placed witnesses to questions probing their creditworthiness. Grace King, for example, married to a laborer, described herself, and was described by other witnesses, as a "poor woman." Her co-witness Magdalen Cosins claimed that Grace was "a poor foolish creature not knowing what it is to swear or forswear, and has had 3 bastards." 37 Both women and men of limited means anticipated potential doubts about their creditworthiness by asserting that they were poor or worth little or nothing, but honest. In other words, they claimed honesty in spite of their poverty, whereas wealthier witnesses could assume creditworthiness because of their means. In 1594, a Cambridge wife, for example, declared that she was "litle or noughte worthe, her debts beinge paid, yet saythe that she getteth hir lyveinge honestlye, as a poor woman." 38

The higher incidence of poverty among women witnesses left them more exposed than their male counterparts to the discrediting tactics sometimes deployed to cast doubt on an opponent's case. Women made up 34 percent of the 617 witnesses whose reputations were subject to discussion by their co-deponents-a far higher figure than women's overall representation in the dataset. More than half ( 55 percent) of the women witnesses discussed by others were worth little or nothing or were poor, whereas only 29 percent of the male witnesses discussed by others were of limited means. However, there was very little difference in the proportions of male and female witnesses who, after having their credibility questioned, were positively endorsed by their co-deponents. Fifty percent of these women, and 48 percent of these men, received favorable or at least mixed appraisals from their co-deponents, suggesting that (for all their shortcomings) women witnesses were defensible. For example, Catherine Stedman, the wife of a weaver from Smarden in Kent, was defended by three of her (male) co-witnesses in 1607 as an "honest and sober woman" who was commonly accounted so among her neighbors. ${ }^{39}$ In a slightly more mixed assessment from 1617, Anne Hills, a married woman who claimed "spinster" as her occupational title, was styled as "a contentious woman amongst her neighbours" but also as a "poor woman \& one who takes pains by her labour to get her living" and unlikely to forswear herself. 40

${ }^{35}$ European civil law procedure prescribed that the "integrity of witnesses should be carefully investigated to assess: their social rank; their honor; whether he is rich or poor, lest he may swear falsely for the purpose of gain." Samuel Parsons Scott, ed., The Civil Law: Including the Twelve Tables, the Institutes of Gaius [...], vol. 1 (Cincinnati, 1932), 232.

${ }^{36}$ Shepard, "Poverty, Labour, and the Language of Social Description"; Shepard, Accounting for Oneself, chap. 4; Hindle, "Bleedinge Afreshe?" See also Bernard Capp, "Life, Love and Litigation: Sileby in the 1630s," Past and Present, no. 182 (February 2004): 55-83.

${ }^{37}$ Wiltshire and Swindon History Centre, Dl/42/56, fol. $17 \mathrm{v}$.

${ }^{38}$ Cambridge University Archives, V.C.Ct.II.1, fol. 42v, Cambridge University Library (emphasis added).

${ }^{39}$ Canterbury Cathedral Archives, DCb/PRC 39/29, fols. 176, 177, 178.

${ }^{40}$ Canterbury Cathedral Archives, DCb/PRC 39/33, fols. 276, 277, 313. 
Table 6-Incidence of Women among Plaintiffs, Defendants, and Witnesses, by Cause Type (\%). Source: Depositions generated by the dioceses of Canterbury, Chester, Chichester, Ely, London, Salisbury, and York, and the Cambridge University courts.

\begin{tabular}{lrrrr}
\hline Cause type & $\begin{array}{c}\text { Total no. } \\
\text { of causes }\end{array}$ & $\begin{array}{c}\text { \% of causes with } \\
\text { female plaintiff(s) }\end{array}$ & $\begin{array}{c}\text { \% causes with } \\
\text { female defendant(s) }\end{array}$ & $\begin{array}{c}\text { \% witnesses who } \\
\text { were female }\end{array}$ \\
\hline Tithes & 274 & 3.2 & 3.2 & 6.2 \\
Defamation & 235 & 61.0 & 46.2 & 38.6 \\
Testamentary & 131 & 40.0 & 36.7 & 29.6 \\
Matrimonial & 82 & 42.3 & 63.0 & 30.0 \\
Pew dispute & 51 & 25.0 & 21.2 & 21.3 \\
Church dues & 44 & 0.0 & 7.3 & 1.8 \\
Adultery/paternity & 18 & 22.2 & 33.3 & 24.2 \\
Office & 12 & 3.2 & 0.0 & 20.4 \\
Dilapidations/charges & 12 & 0.0 & 27.3 & 4.8 \\
$\quad$ vs. parish officials & & & & 28.0 \\
Other & 90 & 13.6 & 12.5 & 24.0 \\
TOTAL & 949 & 26.1 & 24.8 & \\
\hline
\end{tabular}

The gender distribution of witnesses among different types of cause and according to the gender of litigants suggests additional boundaries surrounding women's participation, which further indicates that their incorporation within the legal activities of an expanding state was both partial and contingent. Table 6 compares the incidence of women among both litigants and witnesses, where it can be established, by cause type. ${ }^{41}$ The overall proportions of female litigants and witnesses were roughly consonant at around one-quarter, although a higher proportion of female litigants sued alongside men than that of male litigants entering joint suits with women. However, the extent of women's representation varied considerably according to the business in dispute. Table 7 illustrates this point further by charting the distribution of female and male witnesses according to cause type, additionally distinguishing between women on the basis of their marital status.

The relative frequency of women as both litigants and witnesses in defamation litigation has already been well documented by historians. ${ }^{42}$ As shown in table 7 , twice the proportion of female witnesses gave evidence in such cases compared to male witnesses. However, although women made up a majority of the plaintiffs (61 percent) in this sample of defamation suits, they still remained in a minority of defendants (46.2 percent) and only 38.6 percent of all witnesses produced in defamation suits. As might be expected, women were also well represented in matrimonial

${ }^{41}$ Table 6 represents a sample of causes drawn from the dioceses of Chester, Chichester, Ely, and York, the archdeaconries of Lewes and Richmond, and the Cambridge University courts, owing to the more systematic recording of cause type in these records. The number of causes represents the sample of causes in which witnesses were cited and were asked about their worth, and therefore does not include causes that were initiated but did not lead either to the citation of witnesses or the questioning of witnesses about their worth. Witnesses were interrogated about their worth in up to 83 percent of causes. See Shepard, Accounting for Oneself, 12-13.

42 See note 9 . 
Table 7-Incidence of Witnesses by Cause Type, Gender, and Women's Marital Status (\%). Source: Depositions generated by the dioceses of Canterbury, Chester, Chichester, Ely, London, Salisbury, and York, and the Cambridge University courts.

\begin{tabular}{lrrrrr}
\hline Cause type & All men & All women & Singlewomen & Wives & Widows \\
\hline Testamentary & 36.9 & 49.4 & 45.0 & 52.1 & 48.8 \\
Tithes & 23.8 & 5.0 & 3.3 & 3.7 & 11.5 \\
Defamation & 11.0 & 22.0 & 29.3 & 20.6 & 14.6 \\
Matrimonial & 6.4 & 8.8 & 10.4 & 8.8 & 7.1 \\
Church dues & 4.8 & 0.3 & 0.3 & 0.2 & 0.6 \\
Office & 3.3 & 2.7 & 2.4 & 2.9 & 3.1 \\
Adultery/paternity & 2.6 & 2.6 & 2.1 & 2.5 & 3.4 \\
Charges vs. parish officials & 1.8 & 0.3 & - & 0.3 & 0.6 \\
Other & 9.3 & 8.9 & 7.4 & 8.7 & 10.2 \\
TOTAL & 100.0 & 100.0 & 100.0 & 100.0 & 100.0 \\
\hline
\end{tabular}

causes, comprising a majority of defendants (63 percent), more than two-fifths of plaintiffs, and a nearly one-third of all witnesses.

By contrast, women were heavily underrepresented in cases involving disputes over tithes (a customary tax on produce, owed to the church) and also in the much smaller category of causes over the payment of church dues, for example, toward funds needed for church repairs. Not only were small proportions ( 5 percent or less) of the overall sample of female witnesses involved in both types of business but also men supplied at least 94 percent of the total witnesses in each category, reflecting men's dominance as ratepayers and suggesting that women were comparatively peripheral and their authority was discounted in the more formal parochial affairs associated with customary rights and the payment of rates. ${ }^{43}$ Women were rather better represented in causes disputing seating arrangements in church (although still firmly in a minority), indicating a degree of participation in the brokerage of parochial social hierarchies in church (and beyond) consonant with women's importance to the regulation of credit and reputation. ${ }^{44}$ However, in pew disputes, a higher proportion of female witnesses (15 percent) were cited alongside their husbands, compared to only 9 percent in tithes causes. This result might be linked to the higher proportion of widowed women witnesses cited to depose in tithes causes than married women and shows that marital status played out differently for women depending on the matter in dispute.

Women were comparatively well represented in cases disputing the making of wills and the distribution of movable property after death (that is, testamentary

${ }^{43}$ For the overrepresentation of men, and especially older men, in customary disputes more generally, see Alexandra Shepard, Meanings of Manhood in Early Modern England (Oxford, 2003), 221-30; Andy Wood, The Memory of the People: Custom and Popular Senses of the Past in Early Modern England (Cambridge, 2003), 297-315. See also Nicola Whyte, "Custodians of Memory: Women and Custom in Early Modern England," Cultural and Social History 8, no. 2 (May 2011): 153-73; Tim Stretton, "Women, Custom and Equity in the Court of Requests," in Women, Crime and the Courts in Early Modern England, ed. Jenny Kermode and Garthine Walker (Chapel Hill, 1994), 170-90, at 184.

${ }^{44}$ On pew disputes, see Christopher Marsh, "Sacred Space in England, 1560-1640: The View from the Pew," Journal of Ecclesiastical History 53, no. 2 (April 2002): 286-311. 
disputes) - the cause type that produced the highest number of witnesses in the dataset. Nearly half of all women witnesses gave evidence in testamentary disputes, amounting to 39 percent of all deponents in such cases. ${ }^{45}$ These disputes often revolved around the circumstances of deathbed instructions, and women's relative prominence might be explained in terms of their roles as caregivers to the sick. ${ }^{46}$ However, such cases also involved the evaluation and distribution of movable property and the careful monitoring of rightful claims to a deceased person's goods. Women, especially widows, commonly acted as executors or administrators (more precisely, as "executrixes" or "administratrixes") of deceased estates, outnumbering men in the shouldering of these responsibilities for most of the early modern period. ${ }^{47}$ This proportion was due to a number of factors including demography (husbands usually died before wives, even in second or third marriages) and women's familiarity with household goods. Women's presence might therefore be attributed to their importance in overseeing the appraisal and transfer of a deceased person's movable property, whether or not they were responsible for overseeing the estate. After the death of Elizabeth Rogers, a widow of Whitechapel, London, in 1623, for example, several of her female neighbors testified to the extent and value of her movable property that one William Glover claimed she had entrusted to him for the use and care of her seven-year-old son. Elizabeth Trant, a trumpeter's wife, confirmed that Rogers had asked Glover to keep her bedstead for her son's use "untill he were a man because it was his fathers whoe bought the same." She appraised the remainder of Rogers's property as follows:

viij paire of sheets worth one with another in this examinants Judgment $\mathrm{v}$ s[hillings] or six shillings a paire \& noe more, manie of them being coarse \& worne, 3 dozen of napkins old worth $\mathrm{v}$ s[hillings] a dozen \& noe more in her this examinants Judgment, 32 peeces of old pewter as sawcers disses platters porringers \& other pewter worth together in this examinants Judement $\mathrm{x}$ s[hillings] \& noe more \& saieth that there was bedding brasse Iron \& other things beinge all together in one Roome as also 2 ranges $w[$ hi] ch this examinant did not take good notice of $\&$ therefore she this examinant cannot value them.

Trant reported as well seeing in a chest a piece of gold worth five shillings and "white money" worth eight shillings, and she valued an additional trunk at five shillings. ${ }^{48}$ Women were also comparatively well represented as litigants in testamentary litigation, forming a majority of plaintiffs in some samples from the seventeenth century in causes that often concerned the recovery of debts and other movable

45 This proportion compares favorably with the proportion of female witnesses in testamentary litigation (28.3 percent) in the prerogative court of Canterbury between 1660 and 1700; Lloyd Bonfield, Devising, Dying and Dispute: Probate Litigation in Early Modern England (Farnham, 2012), 230.

${ }^{46}$ Bonfield, Devising; Ralph A. Houlbrooke, Death, Religion and the Family in England 1480-1750 (Oxford, 1998), 191.

${ }^{47}$ Barbara Todd, "Freebench and Free Enterprise: Widows and their Property in Two Berkshire Villages," in English Rural Society, 1500-1800: Essays in Honour of Joan Thirsk, ed. John Chartres and David Hey (Cambridge, 1990), 175-200; Amy Louise Erickson, Women and Property in Early Modern England (London, 1993), 158.

${ }^{48}$ London Metropolitan Archives, London Commissary Court, 9065A/5 [unfoliated], 18 November 1623. 
property ${ }^{49}$ Rather than solely attributable to women's caring responsibilities and their responsibilities as executors and administrators, their relative prominence in testamentary litigation is equally indicative of their integration within credit networks in early modern England. ${ }^{50}$

It would be wrong, therefore, to attribute the presence of female witnesses simply to a circumscribed domain of marriage making, marriage breaking, and sexual reputation. Women's limited participation in tithes cases and disputes over the payment of church dues-most likely because wives would not have been liable to pay either tax and because (older) men were accorded authority as custodians of the customs surrounding their payment-did not mean that women were entirely absent from claims associated with the transfer of money and/or property, as their presence in testamentary disputes confirms. It is also significant that the cases in which widows were relatively well represented compared to married women and singlewomen were those involving tithes and church dues, suggesting that widows might assume at least some of the mantle of authority more commonly associated with male householders. However, it is also inescapable that in cases affording a greater freedom in the selection of witnesses - that is, requiring evidence of local custom rather than incidental presence at an event in dispute-women were more heavily selected out of the witness pool.

In a related set of trends, women witnesses featured much more prominently in causes involving female litigants than male litigants. Women made up over half (53 percent) of the witnesses in suits exclusively fought between women, whereas they only comprised 13 percent of the witnesses called to testify in suits fought exclusively between men. ${ }^{51}$ Women were even more poorly represented among witnesses called in cases brought by or against churchwardens (that is, parish officials), constituting just under 10 percent. It is also possible to chart the incidence of female witnesses within the clusters of witnesses cited per cause, as shown in table $8 .^{52}$ All the witnesses were female in only 4 percent of all causes, whereas 62 percent of causes drew exclusively on male witnesses. Only 9 percent of causes involved a majority of female witnesses.

Female witnesses were very rarely in a majority, therefore, and their presence in court appears to have been heavily influenced by the matters in dispute and the

${ }^{49}$ Lindsay Moore, "Women and Property Litigation in Seventeenth-Century England and North America," in Stretton and Kesselring, Married Women and the Law, 113-38, at 123-25. In the prerogative court of Canterbury, women comprised 46.5 percent of proponents and 46.2 percent of respondents; Bonfield, Devising, 227.

${ }^{50}$ William Chester Jordan, Women and Credit in Pre-Industrial and Developing Societies (Philadelphia, 1993); Marjorie K. McIntosh, "Women, Credit, and Family Relationships in England, 1300-1620," Journal of Family History 30, no. 2 (April 2005): 143-63; Alexandra Shepard, "Crediting Women in the Early Modern English Economy," History Workshop Journal 79, no. 1 (Spring 2015): 1-24; Alexandra Shepard, "Minding Their Own Business: Married Women and Credit in Early Eighteenth-Century London," Transactions of the Royal Historical Society 25 (December 2015): 53-74; Judith Spicksley, "Women, 'Usury' and Credit in Early Modern England: The Case of the Maiden Investor," Gender and History 27, no. 2 (August 2015): 263-92.

${ }^{51}$ In London defamation litigation, female witnesses comprised 60 percent of deponents in causes sued between women, compared to 46.5 percent of deponents in all defamation causes; Gowing, Domestic Dangers, 49.

52 This table refers to a smaller subset of 960 cases, drawn from the dioceses of Chester, Chichester, Ely, and York. 
Table 8-Proportions of Female Witnesses per Cause. Source: Depositions generated by the dioceses of Canterbury, Chester, Chichester, Ely, London, Salisbury, and York, and the Cambridge University courts.

\begin{tabular}{lcc}
\hline \% of witnesses who were female & No. of causes & \% of total causes \\
\hline 0 & 590 & 62 \\
$1-25$ & 90 & 9 \\
$26-50$ & 187 & 20 \\
$51-75$ & 51 & 5 \\
$76-100$ & 42 & 4 \\
TOTAL & 960 & 100 \\
\hline
\end{tabular}

gender of the litigants. Women's voices were relatively absent from disputes involving custom and the payment of dues and from causes concerning formal parish business initiated by local officials, although women were clearly more authoritative in matters surrounding the redistribution of movable property necessitated by death. As far as the social composition of witnesses provides evidence of litigants' preferences (as opposed to women's incidental presence during events that generated disputes), married women were disproportionately represented above their unmarried and widowed counterparts. This pattern is in line with what we know about the relative authority of married women in early modern England; notwithstanding the restrictions of marital property law, wives in many ways exerted more authority and agency than singlewomen or the majority of widows. ${ }^{53}$

When responding to questions concerning their creditworthiness, female witnesses were unable to lay claim to the substantial resources cited by the majority of men in assertions of their means. They were also more likely than men to concede their own poverty, a reflection not only of their more precarious claims to means but also of their greater readiness to depict themselves and be depicted in a position of dependence that was also denoted by the term "poor." For many of these women, exposure to the operation of the law in the church courts did not necessarily provide them with the opportunity of exercising legal agency. Women's presence and the terms on which they participated as witnesses could be hedged with constraints and therefore represents a story of highly qualified inclusion. For example, while a greater social range of women than men may have been included among witnesses, it is possible that this range merely served to confirm female dependence-especially given women's greater facility with the language of poverty and impotence. Furthermore, the evidence suggests that church court proceedings depended on rather than challenged patriarchal norms and expectations and that the same forces that worked to limit women's options as litigants influenced their experiences as witnesses. ${ }^{54}$

${ }^{53}$ David Pennington, Going to Market: Women, Trade and Social Relations in Early Modern English Towns, c. 1550-1650 (London, 2015), chap. 6; Gowing, "Ordering the Body." See also Sofia Ling, Karin Hassan Jansson, Marie Lennersand, Christopher Pihl, and Maria Ågren, "Marriage and Work: Intertwined Sources of Agency and Authority," in Making a Living, Making a Difference: Gender and Work in Early Modern European Society, ed. Maria Ågren (New York, 2017), 80-102.

54 Stretton, Women Waging Law, 43-55, 67-68, 212-14. 
It would appear that ecclesiastical litigation did not simply echo existing attitudes and prejudices but helped to reaffirm and so to sustain them.

It would be hard to argue that many female witnesses before the church courts actively participated in the "collaborative project" of state formation, especially given the equivocal support that common lawyers offered to these bodies. ${ }^{55}$ However, by having their testimony carry weight in the formal adjudication of disputes, they engaged with and participated in the governance of their communities. Whether reluctant or steadfast supporters (or opponents) of the litigants who summoned them, they had the chance to assert or defend their worth as they described it. They were also able to observe and perhaps to learn from the legal dramas they were cast in. The resulting declarations of worth supply valuable evidence to researchers but provided the individuals who made them with an opportunity to declare their standing within their communities and to lay claim to measures of authority, however modest these might have been. These autobiographical statements prompted deponents to reflect on their place in their communities in a manner that arguably became more unusual as the seventeenth century gave way to the eighteenth, during the disruptions of the civil wars and the Republic, and the subsequent decline of party-against-party litigation and as commercial and financial interactions became less personal. Other changes over time also warrant further investigation, such as the growing incidence of female witnessing in the most developed commercial areas of the country and the changing nature of dependence in the context of employment, if not within marriages. Clearly, participation in church court proceedings did not equate with agency, but taking sides in matters of local concern led women into legal arenas where they could experience and to varying degrees influence exercises of authority and leave their marks on proceedings and in the historical record.

55 Breen, "Law, Society, and the State," 385. 